\title{
Os norte-americanos na missão à Amazônia, em 1923 ${ }^{1}$
}

\author{
The North American mission to the Amazon in 1923
}

\author{
LUCIENE PEREIRA CARRIS CARDOSO \\ Laboratório de Geografia Política da Universidade de São Paulo | USP
}

\begin{abstract}
ALDA HEIZER
Instituto de Pesquisas Jardim Botânico do Rio de Janeiro
\end{abstract}

RESUMO O presente artigo resulta das investigações realizadas sobre a presença da missão norte-americana da borracha, a American Rubber Mission (de 1923-1924), na Amazônia. Para tal, foram utilizados os relatórios produzidos pelos membros da referida missão ressaltando sua composição e sua atuação, bem como a apropriação dos resultados para investimentos futuros na região. Estes resultados foram enviados para o governo dos Estados Unidos confirmando a viabilidade do cultivo da borracha para uso da indústria automobilística norte-americana.

Palavras-chave Amazônia - território - missão.

\begin{abstract}
The present article results from investigations carried out about the presence of the American Rubber Mission (1923-1924) in the Amazon. For such were used reports produced by members of the mission highlighting their composition and action, as well as appropriation of the results for future investments in the region. These results were sent to the United States government stating the viability of the rubber cultivation for the North American automotive industry own use.
\end{abstract}

Keywords Amazon-territory-mission.

No contexto das chamadas "missões civilizatórias", ${ }^{2}$ organizadas no início do século XX, quando foram realizadas expedições como a Rondon (1907-1915), a da borracha (1912), a biológica belga Massart (1922-23), entre outras, podemos incluir a missão norte-americana da borracha à Amazônia, em 1923-1924, objeto do presente artigo. As missões científicas ao interior se inseriam no contexto de modernização do país, evidenciando, portanto, alguns temas em comum. ${ }^{3}$

Assim, engenheiros, médicos, geólogos e militares envolveram-se na construção de ferrovias e linhas telegráficas; bem como nas avaliações da Inspetoria de Obras contra as Secas e da Superintendência de Defesa da Borracha. ${ }^{4}$

A atuação de Cândido Mariano da Silva Rondon tinha como objetivo integrar o sertão ao restante do território brasileiro. Sua concepção de nação baseava-se na doutrina positivista, de modo que, para ele, o progresso tecnológico - neste caso, o telégrafo - era o que levaria a civilização àquelas comunidades longínquas. Designado pelo Governo, em 1890, como integrante da Comissão Construtora de Linhas Telegráficas de Cuiabá ao Araguaia, então 
chefiada pelo major Antônio Ernesto Gomes Carneiro, Rondon foi nomeado, dez anos depois, chefe desta Comissão no estado de Mato Grosso, passando a supervisioná-la durante a construção de quase 1.800 linhas telegráficas. Entre 1907 e 1915, foi encarregado de chefiar a Comissão de Linhas Telegráficas de Mato Grosso ao Amazonas (CLTEMTA), conhecida também como "Comissão Rondon". Antes disso, para se ter uma ideia da dimensão dos seus trabalhos, Rondon chefiou a comissão da construção da linha telegráfica entre Goiás e Cuiabá (1890-1898); em seguida entre as cidades de Cuiabá e Corumbá (1900-1904), chegando inclusive às fronteiras do Paraguai e da Bolívia (1905-1906).

Em 1910, fundou o Serviço de Proteção aos Índios e Localização dos Trabalhadores Nacionais e o Escritório Central da CLTEMTA, tendo este último atuado como um organismo de relações públicas e de gerenciamento das atividades dos trabalhos de campo da citada Comissão. Cândido Rondon acompanhou o ex-presidente norte-americano Theodore Roosevelt em uma expedição científica ao Amazonas entre janeiro e abril de 1914. No período de 1915-1919, completou as explorações de rios, a fim de reunir dados para a "Carta geográfica do Estado de Mato Grosso".

\section{A missão mista norte-americana rumo à bacia amazônica ${ }^{6}$}

Desde o final do século XVIII, a borracha consistia em um gênero conhecido entre os europeus. 0 explorador francês Charles-Marie de La Condamine, membro da Academia de Ciências de Paris, após sua expedição pela região amazônica, propagou as utilidades possíveis da borracha em objetos de uso do cotidiano, como garrafas e sapatos. 0 desenvolvimento do método da vulcanização pelo cientista norte-americano Charles Goodyear, em 1839, permitiu maior elasticidade e resistência às alterações da temperatura ambiente. Já em 1876, tal era sua importância que a borracha seria exibida na Exposição Universal de Paris, como produto utilizado em pneus de veículos de tração equina. Antes da popularização do automóvel, o látex seria utilizado, por exemplo, em luvas de borracha na medicina, em brinquedos, em pneumáticos para bicicletas e em preservativos na Inglaterra.?

Não por acaso, em meados do século XIX, a borracha integrava a pauta das exportações como um dos gêneros extraídos da flora e da fauna da região amazônica. A concessão imperial da navegação a vapor no rio Amazonas e em seus afluentes a Irineu Evangelista de Sousa, o Barão de Mauá, em 1853, associada ao processo de vulcanização da Hevea brasiliensis, ampliou o interesse do gênero, desencadeando uma corrida à Amazônia. A navegação possibilitou, ainda, a migração para a região, aumentando consideravelmente a mão de obra disponível para os seringais. Vale acrescentar que em virtude das pressões internacionais, o governo monárquico liberou, em 1866, a navegação no rio Amazonas e em seus principais afluentes para todas as nações amigas, em especial para os Estados Unidos, a França e a Inglaterra. Consequentemente, com a entrada de capital estrangeiro, estabeleceram-se linhas regulares que ligavam diretamente o porto de Manaus aos portos da Europa e dos Estados Unidos. Mais tarde, em 1874, uma companhia de capital norte-americano monopolizava a navegação dos rios Amazonas, Madeira, Guaporé e Mamoré. A introdução e a abertura da navegação permitiu uma transformação nas relações comerciais da economia amazônica, ampliando 0 mercado externo. Em decorrência da grande produção de borracha, a navegação oceânica inseriu a região amazônica na economia de mercado internacional. ${ }^{8}$

Entre 1880 e 1920, a região vivenciou o período de esplendor que se convencionou denominar de belle époque amazônica. Os lucros proporcionados pela exploração e pela comercialização da borracha ensejaram a transformação urbanística e arquitetônica das cidades de Manaus, no Amazonas, e Belém, no Pará. Inspiradas em padrões europeus, seriam construídas avenidas longas e arborizadas, e praças. Foram instaladas linhas de bondes, iluminação a gás, cinemas, teatros, saneamento básico. Havia o afluxo de imigrantes estrangeiros e também de migrantes do Nordeste. A euforia dominava a região amazônica e predominava a certeza de um futuro próspero e seguro, reforçada pela crença na existência de várias áreas ainda inexploradas ou virgens para o cultivo, bem como na superioridade da borracha amazônica. ${ }^{9}$ 
Em 1900, a produção asiática entrava em cena, para mais tarde suplantar a cultura nacional brasileira. Britânicos e holandeses valeram-se das sementes transportadas em 1876 por Henry Alexander Wickham. 0 botânico inglês levou consigo ${ }^{10}$ as primeiras mudas da chamada Hevea brasiliensis da foz do rio Tapajós para serem plantadas no Jardim Botânico de Londres. ${ }^{11}$ As novas sementes que germinaram foram transportadas para colônias inglesas e holandesas na Ásia, alcançando grande êxito. Com a Primeira Guerra Mundial (1914-1918), a borracha amazônica começou a sofrer forte depreciação no mercado internacional. ${ }^{12}$

0 capital estrangeiro ligado à comercialização e à distribuição do gênero deslocou-se do Vale do Amazonas para as plantações do Oriente. Caracterizada pelo seu planejamento, a produção asiática superava o sistema rudimentar amazônico de cultivo e distribuição. As gigantescas plantações de seringueiras asiáticas, com mão de obra barata e abundante, além de transporte acessível e eficiente, desarticularam a produção nacional. 0 governo brasileiro e os produtores envidaram esforços frente à derrocada da borracha.

Iniciativas locais buscaram salvar a economia da borracha amazônica, principalmente no auge de sua crise, quando se perdia espaço para o mercado asiático. Sob os auspícios da Associação Comercial do Amazonas e sob o patrocínio do governo amazonense, organizou-se em fevereiro de 1910 o Congresso Comercial, Industrial e Agrícola.

Em paralelo ao certame, ocorreu uma mostra de objetos e utensílios usados na indústria da borracha. Além de congregar proprietários de seringais, técnicos e economistas, o evento atraiu a atenção de jornalistas do Rio de Janeiro, de Paris, de Nova York e de Londres, além de delegações do Peru, da Venezuela, da Bolívia e da Colômbia. Entre as recomendações dos participantes, destacavam-se: concessões de terras públicas, distribuição de sementes e mudas, incentivos às exportações e incremento da propaganda governamental.

Apesar da atenção internacional, os resultados esperados não foram atingidos, uma vez que o período em que se realizou o congresso coincidiu com o momento de alta valorização dos preços da borracha, não havendo assim um caráter de urgência. Outras iniciativas resultaram ainda no estabelecimento da Liga dos Aviadores em janeiro de 1911 com recursos provenientes do Banco do Brasil, uma experiência análoga à da valorização do café.

Mas a situação não se mostrava favorável, e os auxílios eram escassos. Como a concorrência asiática era cada vez mais presente no mercado mundial, buscou-se a estocagem da borracha visando o aumento dos preços, 0 que resultou em seu perecimento, pois os preços não tiveram uma melhora significativa. ${ }^{13}$

Algumas iniciativas regionais sucederam-se, como a assinatura de alguns acordos e leis entre os governos do Pará e do Amazonas, entre 1909 e 1912. Como parte desta associação, previa-se a realização de uma expedição liderada pelo suíço Jacques Huber ao Oriente. 0 botânico do Museu Paraense Emílio Goeldi, então referência mundial nos assuntos relacionados à produção da borracha, viajou para Ceilão, Sumatra, Java e para a península Malaia para investigar e coletar informações sobre as produções gomíferas daquelas regiões. Apesar dos esforços das elites locais e dos governos paraense e amazonense, percebeu-se a necessidade de vultosos investimentos financeiros, o que naquele momento era inviável, pois a "região amazônica carecia de capitais e de empreendedores que levassem adiante um sistema de cultivo em substituição ao extrativismo da borracha silvestre"14 A crise econômica da borracha iniciou-se em maio de 1910, quando os preços sofreram uma forte queda, depois da maior alta de preços do gênero no mercado internacional. Neste mesmo ano, de acordo com a estatística do governador do Pará, João Antônio Luiz Coelho, a produção da borracha no Acre correspondia a 11.565 toneladas; no Amazonas, a 10.454; e no Pará, a 9.502. Entre os países da América do Sul, o Peru produziu 2.495 toneladas; a Bolívia, 2.486; a Venezuela, 25; ea Colômbia, $18 .{ }^{15}$ Como se observa, os preços continuaram declinando, apesar das tentativas locais. Decidiu-se, então, pela organização do Primeiro Congresso da Borracha em agosto de 1911 no Rio de Janeiro. Participaram representantes do Pará, de Amazonas, do Rio Grande do Norte, da Bahia, do Rio de Janeiro e do Paraná. Não era de se estranhar a presença de diferentes entes federativos, uma vez que o propósito era estimular o cultivo da seringueira em todo o território nacional. Os estados do Pará e do Amazonas, os mais interessados por sinal, reivindicaram a criação de dois bancos de crédito agrícola e hipotecário. A solução não veio como se esperava, mas influenciou as decisões do governo federal. ${ }^{16} \mathrm{Com}$ a finalidade de recuperar mercado e preços e de desenvolver as condições socioeconômicas da região, o governo de Marechal Hermes da Fonseca criou por meio do decreto 2.543-A, de 05 de janeiro de 1912, o Plano de Defesa da Borracha. 
Neste âmbito, seria também estabelecida a Superintendência para a Defesa da Borracha, instituição vinculada ao Ministério da Agricultura, Indústria e Comércio, que estabelecia determinadas medidas a fim de facilitar e desenvolver a cultura da seringueira, tais como: abertura de créditos, redução das taxas de exportação, isenção de impostos de importação do material destinado à cultura da borracha, e a construção de uma via férrea central, ligando a estrada de ferro Madeira-Mamoré às fronteiras do Peru. De todo modo, o discurso de valorização da borracha no cenário econômico brasileiro envolveu autoridades políticas, intelectuais, cientistas, ao lado de comerciantes locais, os quais ressaltavam a importância de projetos intervencionistas estatais direcionados à melhoria das condições de trabalho, ao aperfeiçoamento de técnicas de extração do látex e ao desenvolvimento de sua produção sistemática. No rol dessas preocupações, a questão sanitária constituía outro obstáculo à economia da borracha. A Amazônia, batizada pelo médico Belisário Penna como "um grande cemitério", era assolada por diversas doenças que afligiam a saúde dos seringueiros, tais como a malária, 0 beribéri, a leishmaniose e a difteria, 0 que certamente entravava a cadeia produtiva. ${ }^{17}$

Neste sentido, o projeto de valorização da borracha se estendia para a área da saúde, envolvendo diversos cientistas do Instituto Oswaldo Cruz, liderados pelo médico Carlos Chagas (Lima, 1998). Apesar de todos os esforços depositados pelos cientistas que apresentaram um painel sobre a realidade da região, ampliando o conhecimento a respeito das doenças tropicais, o projeto governamental não se concretizou. Pretendia-se dinamizar a cultura da borracha em bases mais competitivas. Todavia, a morosidade administrativa e a falta de apoio federal atrelada à recusa da aprovação de recursos por parte do Congresso Nacional dificultariam a consecução dos objetivos ambiciosos da Superintendência. Sem ignorar que a sede localizava-se na Capital Federal, distante do centro da crise. ${ }^{18}$

Argumentava-se ainda que as despesas seriam elevadas demais para uma produção que não era considerada tão rentável. Além disso, a guerra viria a desvalorizar ainda mais o preço da borracha amazônica no mercado mundial, bem como as demandas dos estados produtores de café, que canalizavam para si as atenções do Governo Federal. ${ }^{19}$

De qualquer maneira, o consumo internacional da borracha acentuava-se em decorrência do desenvolvimento das fábricas de automóveis. 0 abastecimento provinha das plantações das colônias inglesas e holandesas localizadas na Ásia. Até então, os produtores acreditavam que se tratava de uma fonte inesgotável de lucros devido a um ávido mercado consumidor. Mas alguns sinais já demonstravam que a situação não era tão segura. A Rubber Growers' Association, de produtores, sugeriu a limitação das exportações para o ano de 1918 para cerca de 80\%, uma vez que a oferta crescia acima da procura. Não houve sucesso, porém, e o preço da borracha sofreu uma grave queda em 1921. Com o objetivo de regular a oferta à demanda existente, a Inglaterra instaurou o Plano Stevenson (chefe da comissão, nomeado por Lorde W. Churchill, secretário das Colônias), que pretendia sobretudo proteger os interesses dos plantadores em terras de seu domínio. 0 Plano se estendeu de 1922 a 1928, mas não conseguiu alcançar suas metas, pois havia a resistência dos plantadores holandeses, além da insatisfação dos Estados Unidos com a interferência da Inglaterra na manutenção dos preços do produto ${ }^{20}$

Em virtude da política inglesa, o governo norte-americano decidiu investir diretamente na possibilidade do plantio da borracha em novas áreas que favorecessem o seu desenvolvimento material e econômico. Logo de início, planejaram uma investigação em várias regiões - Filipinas, América Central e América do Sul. ${ }^{21}$ Vale ressaltar que até aquele momento os Estados Unidos consumiam 75\% da borracha produzida nas plantações, o que correspondia a 70\% da produção mundial; além disso, 95\% do gênero extraído das plantações eram controlados pelos governos inglês e holandês.

Depois da depressão econômica em 1910, multiplicaram-se as falências na região em decorrência da falta de demanda. Tampouco se considerava economicamente rentável a utilização dos navios, salvo em plena carga. A economia da borracha na região amazônica permanecia essencialmente pré-capitalista em suas relações de produção e de troca, procurando suprir uma indústria estrangeira continuadamente em desenvolvimento. Apesar do caráter extrativista, corporações europeias e americanas buscaram desempenhar um papel mais decisivo nas relações de produção, muito embora percebessem que os recursos financeiros eram insuficientes devido à resistência da regulamentação e da racionalização da produção. A tentativa de impor relações capitalistas de produção se sobrepujava aos obstáculos ambientais 
e humanos existentes. Somava-se a isso a carência de poder político das elites amazônicas em âmbito nacional para promover programas que combatessem as flutuações de preços e a ausência de apoio do governo federal. ${ }^{22}$

Acreditava-se que a missão oficial norte-americana ao Brasil, além de beneficiar a economia daquele país, poderia estender as suas investigações para outros gêneros da região, tais como madeiras, castanhas, cacau, óleos vegetais, e trazer o desenvolvimento da pecuária, com o progresso e a civilização para aquela parte do território nacional, conforme observou Hannibal Porto, ${ }^{23}$ presidente da Associação Comercial do Amazonas:

(...) a inversão de capitais americanos na Amazônia traria a vantagem de transformar ali rapidamente a rotina, as condições de vida se modificariam por completo, tornando-a de infernal que é, na realidade suportável e medianamente agradável. Haja vista o que eles fizeram no Alto Madeira, transformando lugares pestíferos em região habitável desde Santo Antônio até o término da Estrada de Ferro MadeiraMamoré. $^{24}$

Uma das consequências provocadas pela Primeira Guerra Mundial na Europa foi a perda da posição inglesa como a principal potência do mundo capitalista, uma vez que os transportes marítimos, o fornecimento de importações e os investimentos de capitais seriam afetados pelo conflito armado. Em contrapartida, a economia norte-americana em expansão para além de suas fronteiras, buscava novos mercados para as suas exportações e para o investimento de capitais. As relações comerciais entre os Estados Unidos e o Brasil cada vez mais se estreitavam, tanto que, no final da Primeira República, aquele país era o maior consumidor mundial do café nacional. Além disso, o processo de industrialização brasileiro entre as duas guerras mundiais (até 1945) foi caracterizado pela substituição de importações, mas acolheu também investimentos norte-americanos. ${ }^{25}$

0 estreitamento das relações entre o Brasil e os Estados Unidos pode ser notado por meio da expedição da borracha em 1924. A excursão ao Brasil, que contou com a colaboração de nacionais, recebeu o nome de American Rubber Mission. Incumbida pelo Congresso norte-americano de averiguar e confirmar a conveniência de desenvolver 0 cultivo da borracha na América Latina, a missão reunia especialistas em solos, economia e botânica. Dividida em dois núcleos, foi liderada por William L. Schurz, adido comercial da Embaixada dos Estados Unidos no Brasil. 0 primeiro núcleo era formado por representantes do Departamento de Comércio: 0. D. Hargis, agente especial do departamento de comércio e ex-dirigente das plantações da Continental Rubber Company na Sumatra; Curtis F. Marbut, chefe da divisão de estudo dos solos do departamento de agricultura e ex-dirigente de plantações da U. S. Rubber Company, além de A. O. Pierre e E. R. Byorklund, ambos secretários auxiliares, e Miguel P. Shelley. Formado por representantes do Departamento de Agricultura, o segundo grupo era liderado por Carl De La Rue, botânico especializado na Hevea brasiliensis e sua cultura no Oriente; James R. Weir, botânico e fitopatólogo; E. L. Prizer, entomólogo; e M. K. Jessup, auxiliar e fotógrafo. ${ }^{26}$

Do lado brasileiro, o Ministério da Agricultura, Indústria e Comércio, sob a gestão do presidente Artur Bernardes, organizou a comissão especial, denominada 'Comissão Brasileira de Estudos Econômicos da Amazônia', liderada inicialmente por Hannibal Porto e composta pelo engenheiro Avelino Ignácio de Oliveira, ${ }^{27}$ do Serviço Geológico e Mineralógico do Brasil; pelo botânico do Jardim Botânico do Rio de Janeiro, ${ }^{28}$ João Geraldo Kuhlmann;"29 pelo coronel Raymundo C. Monteiro da Costa, do Ministério de Agricultura, e pelo médico Fernando Soledade, funcionário da rede de saúde pública do Rio de Janeiro e que já havia integrado a CLTEMTA (Comissão de Linhas Telegráficas Estratégicas de Mato Grosso ao Amazonas). ${ }^{30}$ Entretanto, Hannibal Porto haveria de ser deslocado do comitê para representar o Brasil na Exposição de Borracha em Bruxelas (Bélgica), que teria lugar em 1924, sendo então substituído por Avelino Ignácio de Oliveira. Além destes, outros haveriam de ser considerados na comitiva brasileira na qualidade de "auxiliares", sem efetivamente acompanhar o itinerário da expedição - entre eles, Paul Le Cointe, diretor do Museu Comercial do Pará; Enéas C. Pinheiro, inspetor agrícola do Pará, e Raymundo Montenegro, ajudante da Inspetoria Agrícola do Amazonas. 0 encerramento da excursão estava previsto para 13 de maio do ano seguinte, quando esta já teria percorrido os principais rios da região amazônica brasileira, peruana, colombiana, boliviana e equatoriana. 
Ao que tudo indica, havia grande expectativa com a chegada do comitê misto em Belém, noticiada em periódicos locais e nacionais do porte da Folha do Norte e do Jornal do Commercio..$^{31}$ Como a expedição estava agendada para partir no dia 15, os estrangeiros optaram neste ínterim por realizar visitas aos principais centros comerciais e por se dedicar às primeiras pesquisas do solo e do subsolo daquelas localidades. Há o registro da visita ao Museu Goeldi e a um campo experimental de plantações da borracha no Instituto Profissional Lauro Sodré, ao lado do botânico do João Geraldo Kuhlmann (Jornal do Commercio, 10 de agosto de 1923).

A data da partida não poderia deixar de ser emblemática. Tratava-se da comemoração do primeiro centenário de adesão do Pará à Independência do Brasil, em 1823. Vale acrescentar que nem todas as províncias aderiram imediatamente à declaração de D. Pedro I no dia 7 de setembro de 1822 às margens do riacho Ipiranga. A adesão demorou cerca de um ano para se concretizar. Havia resistências por parte de algumas províncias - Bahia, Maranhão e Pará - controladas pelas juntas governativas compostas em sua maioria por elementos portugueses fiéis ao governo lusitano. ${ }^{32}$

De todo modo, os festejos incluíam o desfile de seis mil crianças e uma parada militar (Jornal do Commercio, 16 de agosto de 1923, p. 01). No dia 15 de agosto de 1923, os membros das duas comissões embarcavam no vapor Andirá33, no porto de Belém do Pará. Uma prévia das relações estabelecidas entre os dois grupos foi narrada por KuIhmann. 0 botânico salientava o clima de camaradagem e de perfeita harmonia entre brasileiros e estrangeiros. Por outro lado, noticiava certa frustração em aprimorar os estudos idiomáticos.$^{34} \mathrm{~A}$ imagem a seguir apresenta oficialmente os integrantes do comitê misto em clima de formalidade, atmosfera que acompanhou a excursão. Ao fundo, observase 0 vapor Andirá. A navegação a vapor representou o progresso na região amazônica; teria sido difícil desenvolver expressamente 0 cultivo dos seringais sem a sua utilização, assim como a das canoas, as quais tiveram um papel fundamental, pois transpor a imensa rede de igarapés, furos e lagos para abastecer o interior, as cidades e os próprios seringais consistia em uma árdua tarefa.

Coube ao botânico João Geraldo Kuhlmann a redação do "Esboço de fitogeografia" como arte dos resultados de sua atuação junto à missão norte-americana de 1923 à Amazônia. Dividido em três partes, a primeira seção apresenta 0 levantamento das plantas "econômicas e úteis em geral" encontradas, a partir da enumeração das diversas vegetações localizadas em terra firme, nos terrenos de aluvião e nas margens dos rios. ${ }^{35}$

No que se refere à borracha, o botânico constatou a existência de duas espécies já conhecidas, a Hevea brasiliensis e a Hevea bpruceana, ao lado de uma terceira descoberta ainda em estado de cultura - tratava-se da Hevea buyanensis. ${ }^{36}$

De maneira geral, Kuhlmann apresentou um quadro sobre a distribuição geográfica da Hevea brasiliensis, enfatizando tanto a variedade quanto a diversidade, desde o Baixo Amazonas até 0 alto dos seus afluentes. Mereceram destaque as visitas realizadas às plantações do Instituto Lauro Sodré, no Pará; do Seringal Mirim e de Cachoeira Grande, em Manaus; bem como às regiões dos rios Solimões e Madeira. 0 botânico observou a existência de exemplares jovens do caucho ou da "castilloa elástica", espécimes tradicionalmente utilizados pelos seringueiros e pelos índios na fabricação de produtos impermeabilizantes de uso cotidiano.

Em outra ocasião, Kuhlmann destacou a possibilidade de aprimorar a economia local por meio da cultura de outros gêneros de "valor inestimável", a exemplo da "gutta de abiurana", da família sapotaceae, gênero lucuma. Segundo ele, seus frutos eram apreciados tanto pelas sementes oleosas quanto pelo suco lácteo que fornecia a balata, uma espécie de látex utilizada para a fabricação de isolantes. Outras espécies viáveis seriam: o babaçu, a andiroba, o louro mamori, o bacaba, o jaboti, entre outros.

Algumas impressões da viagem foram por ele relatadas, e publicadas mais tarde no Boletim do Museu Botânico Kuhlmann. ${ }^{38}$ Como representante oficial daquela instituição, o botânico apresentou uma espécie de relatório sobre sua participação na missão oficial e as observações pessoais sobre a região e a viagem de maneira geral. Ao chegar ao lado boliviano da região amazônica, revelou algumas informações sobre uma vila local: "A vila tem uns dois mil e 
quinhentos habitantes, e as casas são quase iguais (...) as ruas não possuem calçada e nos cruzamentos existem vigas de madeira." ${ }^{38}$ Chamaram-lhe a atenção os tipos locais - neste caso, verificou a predominância da origem indígena da população. Depois de atravessar outros rios, Kuhlmann permaneceu cerca de um mês a bordo de um navio, no qual comemorou o seu $41^{\circ}$ aniversário e continuou a organizar o material levantado. E mais: verificou a presença de uma planta de valor até então não confirmado, uma resina que recebia o errôneo nome de "chicle". ${ }^{39}$ Tratava-se da "tamanqueira de leite" ou "condura de espinho", que, pelas qualidades físicas e aromáticas, poderia vir a substituir a goma de mascar importada. ${ }^{40}$ Em maio de 1924, Kuhlmann retornava ao Rio de Janeiro com cerca de 1.500 exemplares recolhidos, entre espécies vegetais e borboletas, ao herbário do Jardim Botânico. ${ }^{41}$

Os registros de Kuhlmann fazem parte de um manancial de informações que foram caras aos norte-americanos e que, associadas às conclusões da missão brasileira e norte-americana sobre as regiões visitadas, foram reproduzidas no Relatório de Avelino Ignácio de Oliveira. Ali se conclui que o Vale do Amazonas possuía grande potencial para produção de sementes da borracha, em especial a faixa que se estende pela serra de Paricatuba, pelos planaltos do Xingu e de Boim, e pela serra de Parintins. Do ponto de vista topográfico, o solo possuía condições ideais para o cultivo, com exceção da pequena quantidade de chuvas da área. As informações levantadas pela American Rubber Mission e enviadas para o governo dos Estados Unidos confirmavam a viabilidade do cultivo da borracha para uso da indústria automobilística norte-americana.

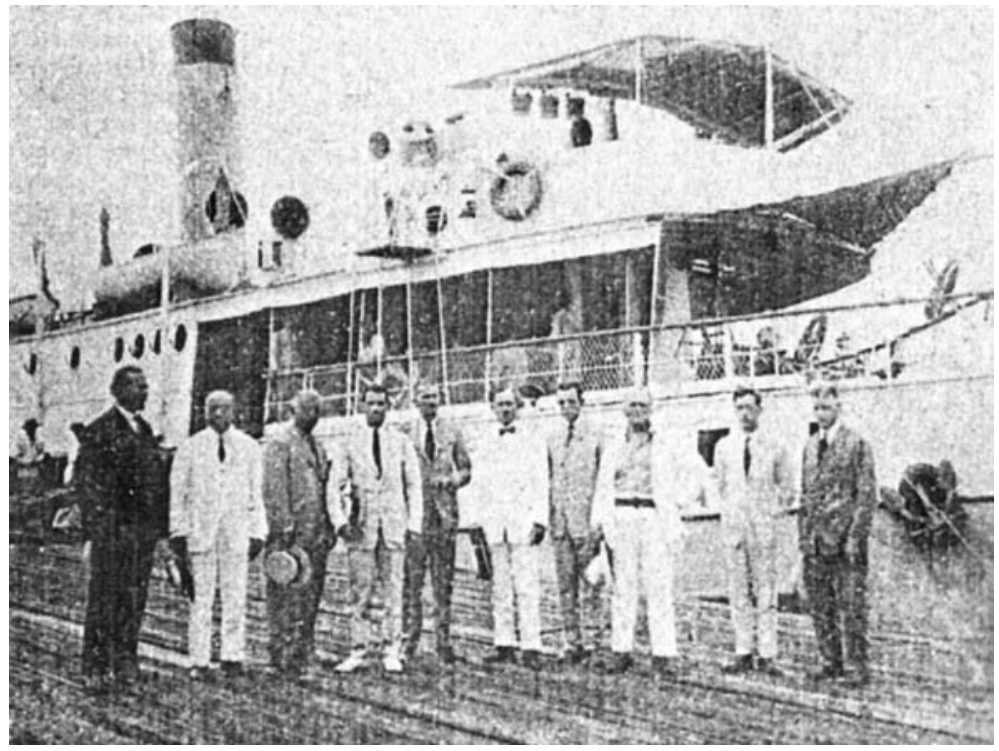

Fig 10 botânico João Geraldo Kuhlmann (primeiro à esquerda, de terno escuro) Biblioteca Barbosa Rodrigues do JBRJ (BOLETIM DO MUSEU BOTÂNICO KUHLMANN, IBDF, Jardim Botânico, ano 7, n. 1, jan-fev-mar, 1984, p.15)

Planejada para perdurar entre oito e dez meses, a missão oficial brasileira e norte-americana percorreu diversos pontos do Vale do Amazonas, estendendo-se do Pará até Iquitos, no Peru, passando pelo Mato Grosso e pela Bolívia. Ignácio Avelino de Oliveira redigiu um relatório de 476 páginas para o Ministro da Agricultura, Miguel Calmon du Pin e Almeida, e nele, além das observações técnicas e científicas sobre a cultura da Hevea brasiliensis, pretendia apresentar um "inquérito especial" sobre aquela região. 0 documento é dividido em uma introdução e mais cinco partes: itinerário e observações locais; geologia, fisiografia e solos; esboço de fitogeografia; exploração de borracha e outros produtos; estatísticas dos estados de Amazonas, do Mato Grosso, do Pará e da República do Peru. ${ }^{42}$

A expedição seguia um determinado método: em cada localidade visitada, a comissão norte-americana realizava análises do solo. 0 processo consistia na aplicação de uma sonda manual que extraía um número variado de amostras. Tais materiais, então recolhidos, seriam examinados pelo Departamento de Agricultura norte-americano, sediado em Washington. As análises químicas e físicas envolviam a classificação e a avaliação da estrutura, da cor, da textura, da produtividade e do grau de oxidação. Na região de Paraná-Mirim, na cidade paraense de Óbidos, por exemplo, a cerca de um quilômetro de Belém, Avelino Ignácio informava que "descemos todos a terra e cada um cuidou de seu trabalho. Os botânicos foram ver algumas seringueiras da plantação e o especialista em solos, com a sonda manual extraiu três amostras do terreno para análises até a profundidade de $1 \mathrm{~m} 50 \mathrm{~cm}$, encontrando material aluvião e ótimo terreno para qualquer cultura". ${ }^{43}$ Uma ideia de tal procedimento pode ser notada na foto a seguir, que apresenta o geólogo norteamericano Curtis Marbut extraindo mostras do solo e do subsolo: 


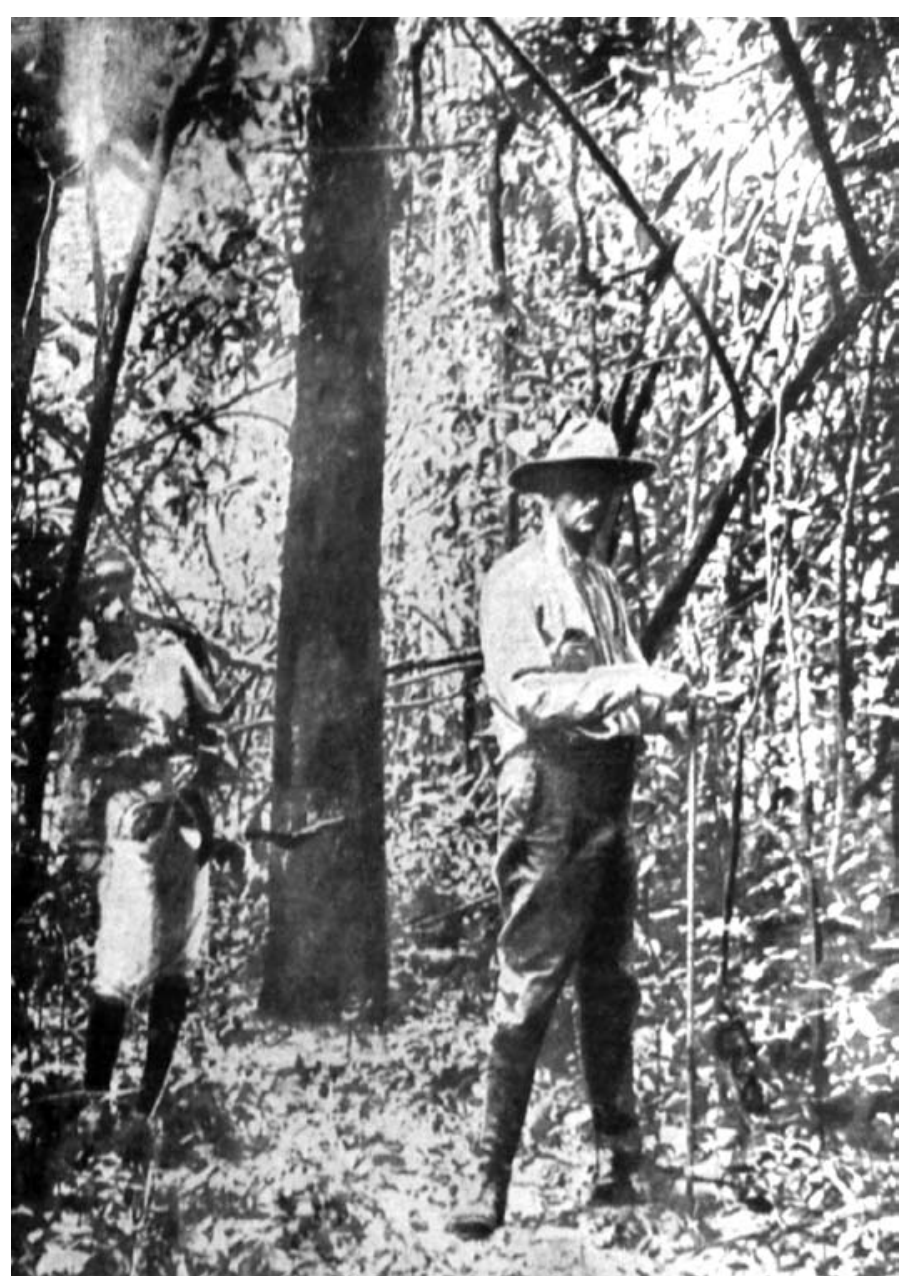

Fig 20 geólogo norte-americano Curtis Marbut, com a sonda manual, extrai mostras do solo e do subsolo (RELATÓRIO DA COMISSÃO BRASILEIRA JUNTO À MISSÃO OFICIAL NORTE-AMERICANA DE ESTUDOS DO VALE DO AMAZONAS. Rio de Janeiro: Oficinas Tipográficas do Serviço de Informações do Ministério da Agricultura, 1924)

região amazônica, Le Cointe desenvolvia pesquisas sobre o cultivo da borracha em sua propriedade, denominada Cocal, à margem direita do rio Amazonas. Nesta ocasião, Avelino Ignácio examinou o método da plantação, observou que as árvores estavam todas catalogadas e que seu plantio não seguia um alinhamento determinado. Constatou também que algumas localidades visitadas padeciam devido às constantes cheias do rio Amazonas, a exemplo da cidade de Parintins, cuja economia, anteriormente voltada para a cacaucultura, redefinia-se com a plantação da erva do guaraná e a criação de gado. Sobre as condições sanitárias e socioeconômicas de Parintins, o líder da comitiva nacional revelava que "esta cidade não dispõe de saneamento algum; a sua população utilizase da própria água do rio Amazonas para todos os usos, sendo o seu transporte feito no ombro" ${ }^{46}$ Depois do exame dos diversos seringais existentes ao longo dos rios Madre de Dios, Orton, Acre, Abunã e seus tributários, a comitiva aportou na cidade boliviana de Riberalta. Nada escapava à pena do líder. Desta feita, ele salientava
À medida que os relatórios parciais iam sendo preparados pela comissão norte-americana, estes eram remetidos para o Bureau of Foreign and Domestic Commerce para a Rubber Division, em Washington, que reunia dados sobre diversos assuntos, tais como: locação e área, população e qualidade do trabalhador, condições de vida, sistema de remuneração e religião, clima, elevação, queda de chuva, ventos, efeitos dos ventos, saúde e estado sanitário, vegetação e produtos florestais, custo e preparo das terras, agricultura principal, distribuição da borracha, árvore da borracha, produtividade e espécies cultivadas, e natureza de terras. ${ }^{44}$ Com objetivos específicos, a biodiversidade da região amazônica seria valorizada e ressaltada na imagem escolhida para o frontispício do relatório brasileiro, como se observa na figura 3.

Do porto de Belém, a comissão mista veio acompanhada do geógrafo francês Paul Le Cointe, presidente da Associação Comercial do Pará e cônsul da França e da Bélgica. ${ }^{45}$ Estudioso da

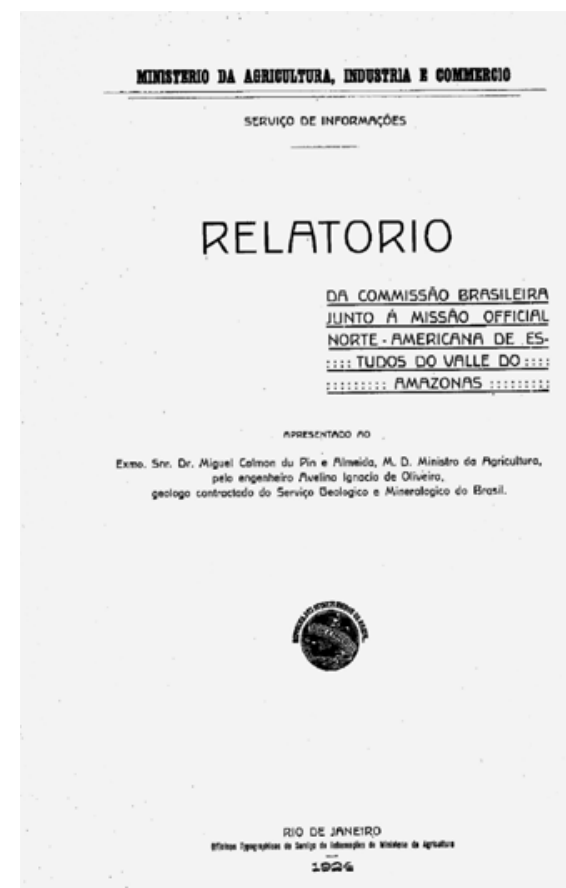

PHL 015231

Fig 3 Frontispício do Relatório da Comissão Brasileira junto à missão oficial norte-americana de estudos do Vale do Amazonas. Rio de Janeiro: Oficinas Tipográficas do Serviço de Informações do Ministério da Agricultura, 1924 (Biblioteca do CPRM) 


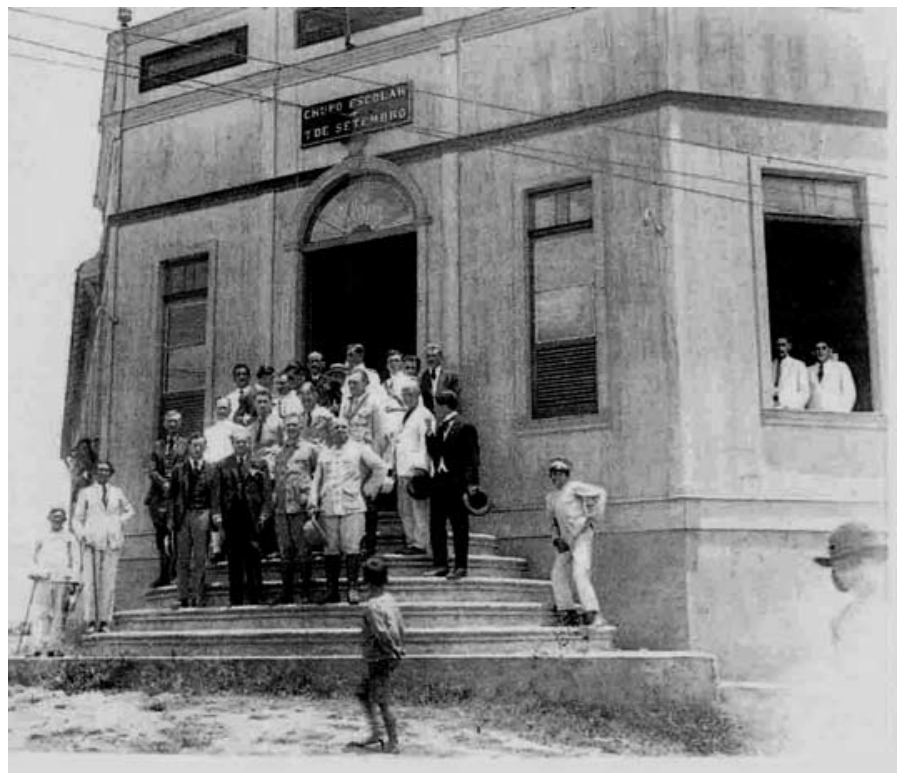

Fig 4 Membros da Missão com moradores e autoridades locais em frente a uma escola na Amazônia. Acervo Muma/JBRJ

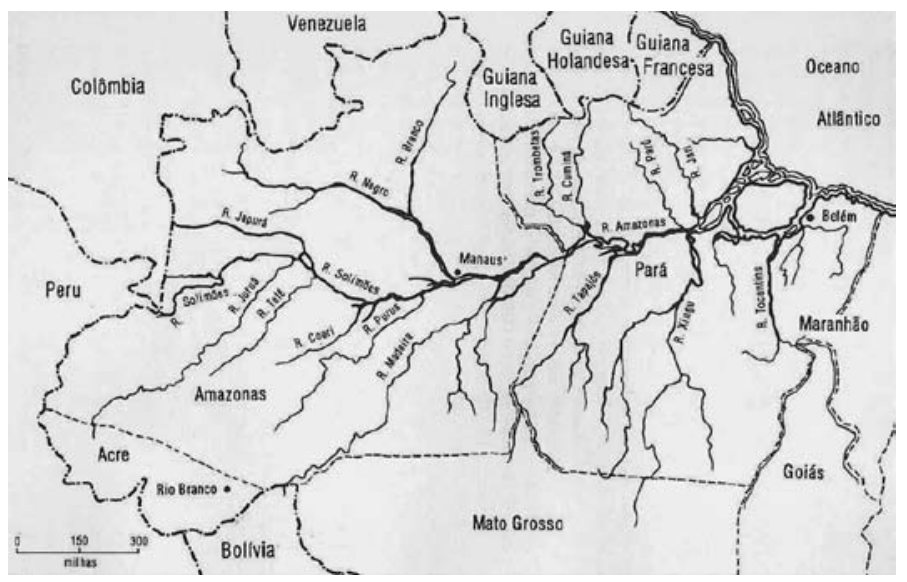

Fig 5 A Amazônia brasileira por volta de 1910 (WEINSTEIN, Bárbara. A borracha na Amazônia: expansão e decadência, 1850-1920. São Paulo: Hucitec, 1993, p. 20. [Coleção Estudos Históricos]. que "a população de Riberalta chama a atenção do visitante, especialmente pelo uso que fazem as mulheres do povo de uma mantilha preta sobre a cabeça, pendente sobre os ombros. As moças de elite social substituem a mantilha negra pelo toucado à moda de Paris. De modo geral, a população parece retraída e pouca festiva" ${ }^{47}$

Já no povoado de Fortaleza, em território acreano, ${ }^{48}$ onde existia um porto de abastecimento de navegação do alto Abunã, registrou-se a existência de inúmeras embarcações, algumas transformadas em "casas comerciais ambulantes" pelos imigrantes sírios. Um banquete foi oferecido por um grande proprietário de terras da região: "um jantar completo cercado pela população trazida ao local pela curiosidade, em que até a água mineral Perrier figurou" ${ }^{49} \mathrm{Na}$ região do rio Branco, a comissão mista visitou uma plantação de balata na Serra de Caracacaí..$^{50}$ Verificou-se que 0 sistema de extração do látex das árvores consistia no mesmo processo utilizado pelos balateiros das Guianas. 0 sistema envolvia a escalação dos troncos com auxílio de esporas de aço e no retalhamento das suas cascas, ocasionando a derrama da seiva da borracha - um procedimento considerado inadequado, uma vez que provocava a morte das árvores. ${ }^{51}$

A parada em cada localidade atraía a curiosidade dos moradores e por sinal o interesse das autoridades locais. Na ocasião, por meio da visita às construções arquitetônicas e às instituições existentes, por exemplo, pretendia-se demonstrar o grau de civilidade e de progresso da região, ressaltando-se as qualidades e as facilidades

locais para o possível desenvolvimento do cultivo da borracha. Tal prática haveria de ser seguidamente repetida em várias regiões visitadas - e a figura 4 representa esta ocorrência.

Considerada a maior bacia fluvial do mundo, a bacia amazônica corresponde a uma área de sete milhões de quilômetros quadrados, abrangendo diversos países da América do Sul, além de Brasil, Peru, Colômbia, Equador, Venezuela, Guiana e Bolívia. Principal rio da bacia, o Amazonas nasce na Cordilheira dos Andes, no Peru, recebe 0 nome de Solimões ao entrar no Brasil e desagua, então, no Oceano Atlântico. Entre os seus afluentes, encontramse os rios Xingu, Tapajós, Negro, Purus, Madeira e Juruá, todos enormes e com características distintas. 0 sistema fluvial é complementado pelos rios tributários, alimentados por afluentes secundários, ribeirões, igarapés e braços que atravessam a região, alimentando, ainda, lagos e lagoas. Para completar a missão, os integrantes da comissão mista percorreram diversos rios e afluentes. Uma ideia da complexidade do sistema fluvial amazônico pode ser apreendida pelo mapa apresentado na figura 5. 
Navegando pelo rio Solimões, em direção ao Peru, a comissão mista visitou a localidade de São Paulo de Olivença, no estado do Amazonas, onde se separou. Um grupo examinou o solo e a vegetação da floresta, enquanto o outro visitou a propriedade da Missão Apostólica de Tocantins, cujos missionários possuíam uma embarcação utilizada para evangelizar a população ribeirinha. ${ }^{52}$ Em lquitos, no Peru, a comitiva deparou-se com cerca de 200 indígenas trabalhando na exploração da balata. Nas proximidades da Cordilheira dos Andes, venceu as correntezas do rio Marañón, alcançando a região do Pongo de Manseriche, onde diversas amostras do solo foram coletadas. Novamente, avistou indígenas, identificados como "índios chaparas, aguarunas e huambisas" - estes últimos descritos como "numerosos e maus" (Idem, p. 210). Na véspera de carnaval, a comitiva organizou um evento em homenagem à sociedade iquitense, com direito a serpentinas, confetes e lança-perfumes. A festa de carnaval organizada trazia marcas das festas realizadas em capitais, transpondo inclusive pequenos detalhes. Neste caso, ao envolver as elites locais e os integrantes da comissão mista, a etiqueta do evento previa o envio de convites formais, como se vê na figura 6.

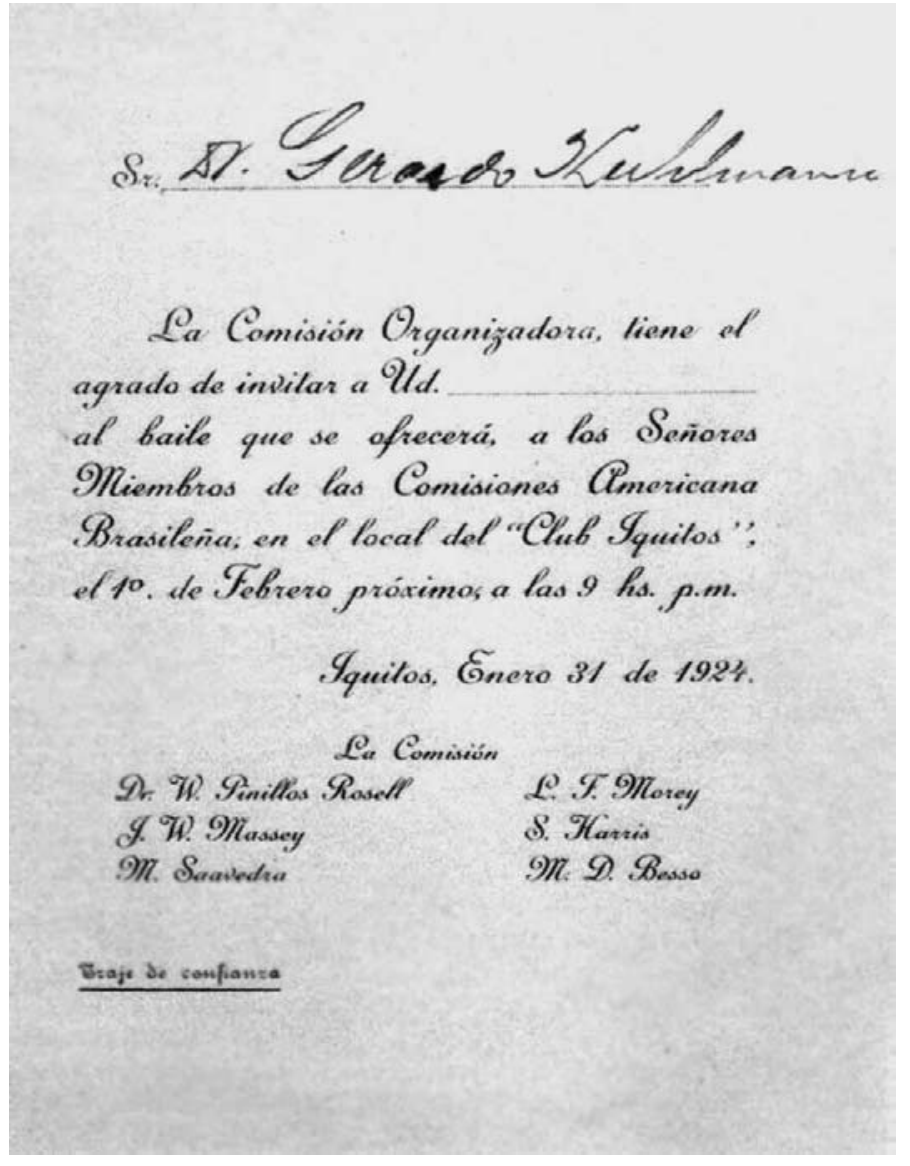

Fig 6 Convite dirigido ao botânico João Geraldo Kuhlmann para o baile. Acervo Muma/JBRJ

francês Henri Coudreau; e o capitão Pedro Dantas, da Comissão Rondon; entre outros. Observou que a falta de iniciativa, associada à pouca densidade da população e às endemias, atravancavam o progresso do Baixo Xingu. Em Altamira, município paraense, destacou ainda a falta de acesso aemeios de comunicação, tais como 0 telégrafo e 0 telefone ${ }^{54} 0$ líder da comitiva norte-americana, William Schurz, concluiu que "a Missão havia encontrado no estado do Pará e pesquisado na Bacia do Amazonas, terras excelentes, condições climatológicas ótimas, salubridade boa e sobretudo um governo honesto, que sabe cumprir a lei, que é uma questão essencialmente valorosa para os capitalistas norte-americanos". ${ }^{55}$

Desde o início, já estava prevista uma excursão ao estado da Bahia. Em pouco mais de 20 dias, os integrantes da comissão excursionaram pela zona da Estrada de Ferro de Nazareth até o rio da Contas, visitando sob a chuva 
intermitente algumas localidades. Nesta oportunidade, além de Avelino Ignácio de Oliveira, na qualidade de geólogo e líder da comitiva brasileira, integrou o grupo o especialista de geologia, fauna e flora baianas, Gregório Bondar. ${ }^{56} \mathrm{Em}$ junho de 1924, a comissão norte-americana retornava aos Estados Unidos a bordo do vapor Western World. De lquitos, no Peru, os integrantes brasileiros Fernando Soledade e João Geraldo Kuhlmann regressaram para o Rio de Janeiro. Raymundo Monteiro da Costa permaneceu em Belém, onde pretendia organizar as suas notas de viagem, e também coletar sementes oleaginosas para o mostruário federal do Pavilhão Britânico da Exposição do Centenário, no Rio de Janeiro, cedido ao Brasil depois deste certame. ${ }^{57}$

\section{Considerações finais}

Ao contrário do relatório brasileiro organizado por Avelino Ignácio, o qual pretendia apresentar uma espécie de inquérito especial sobre o noroeste do território nacional, o relatório norte-americano elaborado por William Schurz ateve-se exclusivamente às informações sobre as potencialidades de produção da borracha no vale amazônico. Na verdade, tal documento consistia em uma das quatro publicações encomendadas pelo Congresso dos Estados Unidos, e pretendia "to investigate and report on the possibilities of developing the rubber-plantation industry in the Philippine Islands and Latin American". ${ }^{58}$ Separado em duas partes, a primeira concentra-se na descrição histórica do cultivo na borracha no vale amazônico até 1924 e as possibilidades de desenvolvimento. Quanto à segunda parte, dividida em nove seções, abarca fundamentalmente o Alto e o Baixo Amazonas, além de Pará, Acre, Bolívia, Peru, Colômbia e Equador. Segundo Schurz, a região investigada correspondia a cerca de três quartos do território norte-americano, excluindo 0 Alasca. Em cada área examinada, foram levantados dados sobre: localização, características físicas, clima, vegetação, condições sanitárias, transportes, população e mão de obra disponível.

Nesta esfera, Schurz observou que a carência de trabalhadores para cultivo poderia ser solucionada com a introdução de contingentes dos estados do Maranhão, do Piauí, da Paraíba, do Rio Grande do Norte e, em especial, do Ceará, que sofria de secas periódicas. ${ }^{59}$ De todo modo, ressaltava a superioridade do trabalhador do vale amazônico: " (...) As a rule, the laborer of the Amazon is of good physique, inured to exposure and under proper incentive capable of long-continued effort. Man for man he could possibly be classified as superior of Indian and Javanese labor used on the rubber plantations of the Orient and at least equal in efficiency of Chinese labor" (Idem, p. VIII). ${ }^{60}$ Sobre as características raciais, registrou a miscigenação entre os portugueses, indígenas e afrodescendentes como um traço comum.

Presumiu-se também que o tempo necessário para implantação de uma área destinada ao cultivo da borracha na região amazônica era inferior a de uma área de produção similar no Oriente. Outro fator favorável ao cultivo da borracha correspondia à forma de apropriação de terras que poderiam ser facilmente compradas, arrendadas ou ainda concedidas gratuitamente pelo Governo. Quanto aos impostos territoriais ou de exportação, estes poderiam ser reduzidos substancialmente para incentivar a entrada de capital externo. Certamente, ao lado de outros atrativos, tais facilidades comerciais e tributárias colaboraram para as condições ideais de implantação da empresa do norte-americano Henri Ford naquela parte do território.

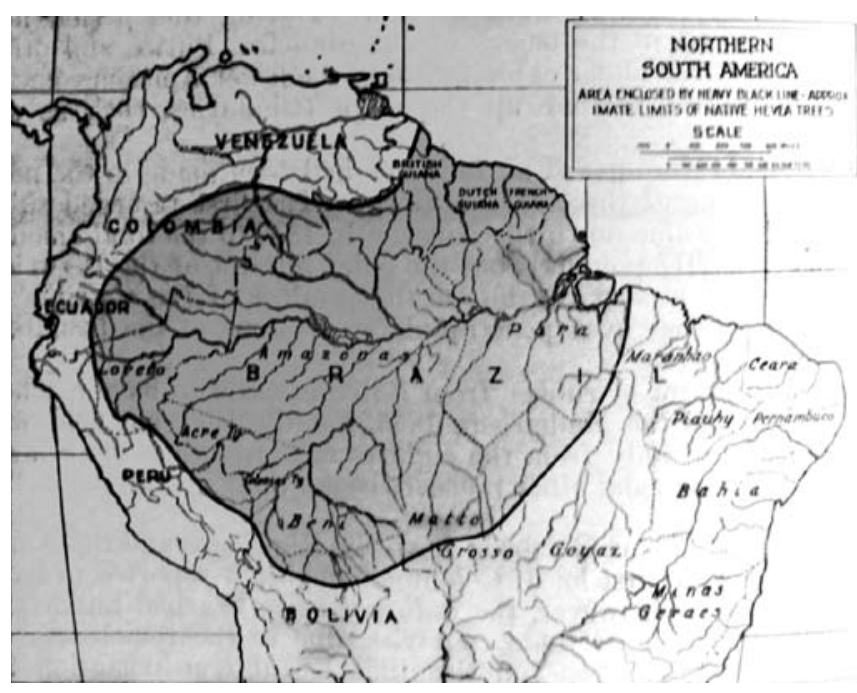

Fig 7 Área definida com os limites das árvores da borracha (SCHURTZ, William. Rubber Production in the American Valley. United States: Depart. of Commerce, 1925, p. 4) 


\section{DEPARTMENT OF COMMERCE

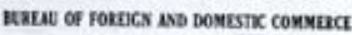 JuLUS KLEN, Dusctoa}

TRADE PROMOTION SERIES-No. 23

CRUDE RUBBER SURVEY

\section{RUBBER PRODUCTION IN THE AMAZON VALLEY}

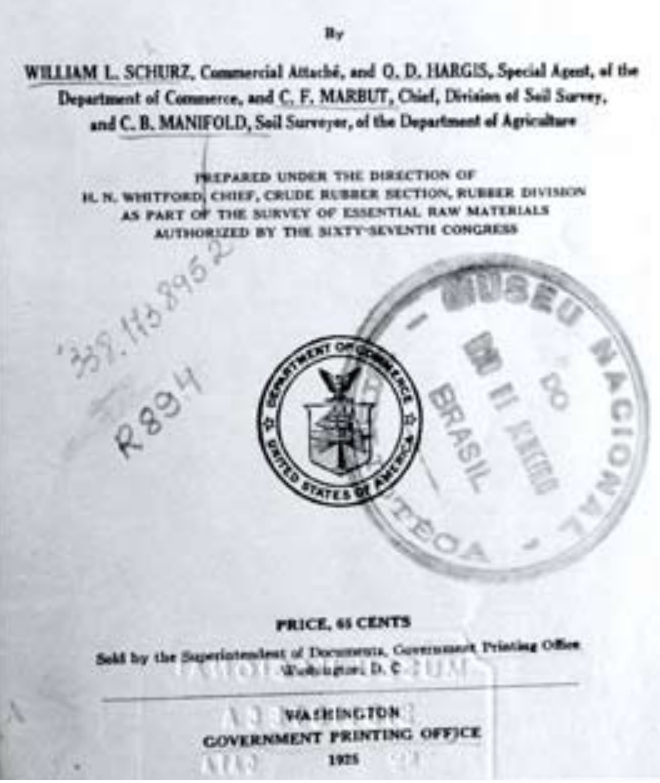

Fig 8 Frontispício do relatório norte-americano organizado por Schurz

Assim, as terras destinadas ao cultivo da Hevea brasiliensis no Vale do Tapajós, em 1927 foram concedidas à empresa Cia. Ford Industrial do Brasil, de propriedade do empresário norte-americano Henry Ford, grande difusor do automóvel e idealizador do sistema de produção industrial em massa. ${ }^{64}$ Os investimentos de Henri Ford no Brasil correspondem a duas localidades e a dois períodos. Entre 1928 a 1934, em Fordlândia. Entre 1935 e 1940, em Belterra. Entre 1940 e 1945, os investimentos tornaram-se inexpressivos. A Fordlândia, por exemplo, foi idealizada como uma "cidade empresa", planejada na região amazônica sob a direção do norte-americano Einar Oxholm. Transplantaram-se os planos urbanísticos dos subúrbios americanos para aquela parte do território nacional. Uma cidade modelo foi projetada, com saneamento básico, luz elétrica, hospital, igreja, lojas, escolas e até cinema. Ao lado disso, foram construídas vilas de casas para os operários.
Em que pese 0 caráter comercial e econômico da expedição que buscava examinar a viabilidade do cultivo da borracha na região amazônica, em função dos interesses estadunidenses e brasileiros, os integrantes da missão buscaram traçar o levantamento da fauna e da flora, da climatologia e da geologia, trazendo à baila também dados sobre a população local, os hábitos e costumes, as condições sanitárias, bem como a distribuição da borracha e as espécies cultivadas da região amazônica. Ao que tudo indica, o relatório apresentado almejava oferecer um quadro geral da região amazônica. Deste modo, os relatórios de viagem podem ser observados do ponto de vista geográfico, socioeconômico e cultural, uma vez que constroem um retrato do Brasil, das imagens das cidades-fantasmas e dos surtos de progresso, além do povoamento, ressaltando ainda a importância do ideário cientificista. ${ }^{61}{ }^{62}$ Avelino Ignácio de Oliveira apontava ainda para inúmeras questões de detalhes:

\section{“(...) do campo vasto que vai oferecer à investigação de todos os problemas econômicos da Amazônia, o inquérito especial sobre a borracha envolverá inúmeras questões de detalhes como por exemplo a exploração dos seringais nativos, a plantação, o custo de produção, a mão de obra e as diversas possibilidades de imigração, sistemas tributários, o empecilho dos impostos de exportação, conces- sões de terras do Estado, arrendamento dessas terras, oportunidades industriais e facilidades de transportes. ${ }^{\prime 63}$}

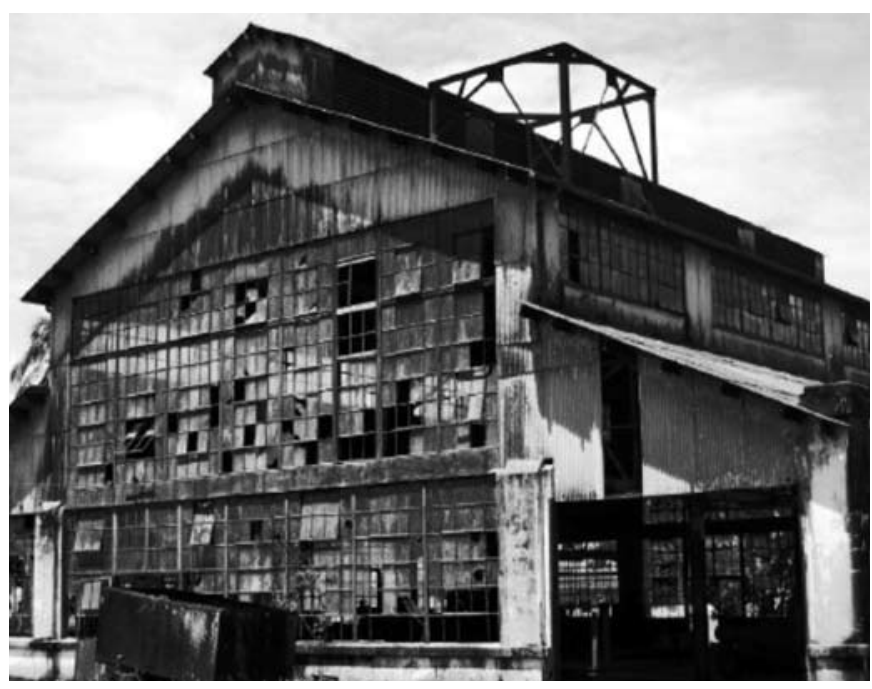

Fig 9 Imagem da década de 1980 de um barracão que abrigava o escritório, o almoxarifado e a seção de eletricidade da Fordlândia (SENA, Cristovam. Fordlândia: breve relato da presença americana na Amazônia. Cadernos de História e Ciências, São Paulo, v. 4, n. 2, p. 89-108, 2008. Disponível em: http://periodicos.ses. sp.bvs.br/scielo.php?script $=$ sci arttext\&pid $=\$ 1809-76342008000200005 \& \operatorname{lng}=$ pt\&n $\mathrm{rm}=$ isogtlng=pt. Acesso em 09 de setembro de 2011). 
A empresa de Henry Ford durou cerca de 18 anos (1927-1945). 0 projeto fracassou, em parte, pela falta de critério para selecionar o terreno ideal, pois a topografia acidentada e o solo arenoso impediam o cultivo mecanizado, associado ao clima úmido, que disseminou um fungo até então desconhecido pelos norte-americanos. Ao que tudo indica, o corpo técnico enviado careceu de especialistas da área agrícola, tais como agrônomos ou botânicos. Além disso, a população local não estava acostumada com o modelo importado de divisão de trabalho, o que gerou sérios conflitos que, associados àquelas pragas que dizimaram as plantações, ocasionaram a baixa produtividade e a desistência do empreendimento, legando ao Brasil um desastre ecológico ${ }^{65}$ e 0 total abandono. ${ }^{66}$

Segundo Prado e Capelato, a inviabilidade do cultivo da borracha em território nacional foi motivada pela carência de uma política de defesa do gênero e pela falta de reinvestimentos do governo brasileiro no setor de produção. Historicamente os produtos primários sempre estiveram dependentes das variações do mercado internacional, como os riscos de concorrentes atrelados ainda à oscilação dos preços. Já no final da Segunda Guerra Mundial, em 1945, a demanda pela borracha natural havia diminuído, e esta seria substituída pela sintética. bo Dessa forma, a missão mista oficial brasileira e norte-americana, além de oferecer informações e dados para as possíveis ações governamentais posteriores, contribuiu para o conhecimento do hinterland nacional e para a implantação do referido empreendimento na selva amazônica, deixando para trás uma cidade esquecida.

\section{Notas e referências bibliográficas}

Luciene Pereira Carris Cardoso é pós-doutoranda do Laboratório de Geografia Política, da Universidade de São Paulo, desenvolve pesquisa sobre "As fronteiras pátrias brasileiras (1883-1909)", financiada pela Fundação de Amparo à Pesquisa de São Paulo, sob a supervisão do Prof. Dr. Antônio Carlos Robert Moraes. E-mail: lucienecarris@hotmail.com.

Alda Heizer é doutora em História das Ciências pelo IG/Unicamp, desenvolve pesquisa sobre coleções científicas no Instituto de Pesquisas Jardim Botânico do Rio de Janeiro e é professora de História da Botânica no programa de Pós-graduação da Escola Nacional de Botânica Tropical/JBRJ. E-mail: aldaheizer@jbrj.gov.br.

10 presente artigo é parte dos resultados da pesquisa para o projeto "Coleções científicas em museus e jardins botânicos: as imagens, o campo e as coleções", coordenado pela pesquisadora Alda Heizer, do Instituto de Pesquisas do Jardim Botânico do Rio de Janeiro. As autoras participam do Grupo de História das Ciências na Amazônia, coordenado pelos pesquisadores Nelson Rodrigues Sanjad e Júlio Cesar Schweickardt, da Coordenação de Informação e Documentação do Museu Paraense Emílio Goeldi. Os objetivos do grupo são "dar visibilidade para as pesquisas históricas sobre a Amazônia; incentivar o desenvolvimento de novas investigações sobre a história das ciências na região (com suas múltiplas relações disciplinares, como antropologia, geografia, botânica, zoologia, geologia, etc.); institucionalizar a disciplina História das Ciências nas instituições de ensino e pesquisa regionais; criar instrumentos para o intercâmbio entre pesquisadores e instituições que trabalham com o tema, como seminários, publicações conjuntas, etc.; e contribuir para a localização e preservação de acervos e fontes históricas relacionados ao tema. Espera-se, como principais repercussões do grupo, a formação de novos pesquisadores na área, 0 incremento da produção científica e a divulgação de fontes relacionadas à prática científica na Amazônia". Disponível em: <http://dgp.cnpq. br/buscaoperacional/detalhegrupo.jsp?grupo $=0029705$ PY5FR08 $>$.

2 LIMA, Nísia Trindade; HOCHMAN, Gilberto. Condenado pela raça, absolvido pela medicina: o Brasil redescoberto pelo movimento sanitarista da Primeira República. In: MAIO, Marcos Chor; SANTOS, Ricardo V. Raça, ciência e sociedade. Rio de Janeiro: Fiocruz/Centro Cultural do Banco do Brasil, 1996. LIMA, Nísia Trindade. Missões civilizatórias da República e interpretação do Brasil. História, Ciências, Saúde - Manguinhos, v. V (suplemento), p. 163-193, jul. 1998. SÁ, Dominichi Miranda de; SCHÄFFNER, Wolfang; LIMA, Nisia Trindade; PODGORNY, Irina (Org.). Caminhos, comunicações e ciências. História, Ciências, Saúde - Manguinhos, v. 15, n. 3, jul.-set. 2008.

3 A historiadora discorre de forma precisa sobre as expedições astronômicas entre meados do século XIX e início do século XX, assunto pouco explorado pela historiografia sobre a temática. Apesar da relevância do tema, as pesquisas históricas nos últimos vinte anos - ao menos aquelas que têm se debruçado e privilegiado diferentes aspectos dessas expedições - têm dado pouca importância ao significado das práticas dos naturalistas e à análise de seus registros, fora de seu lugar de produção original (BARBOZA, Christina Helena da Motta. Ciência e natureza nas expedições astronômicas para o Brasil [1850- 1920]. Boletim do Museu Paraense Emílio Goeldi. Belém, v. 5, n. 2, p. 273-294, mai.-ago., 2010).

4 SCHWEICKARDT, Julio Cesar. Ciência, nação e região: as doenças tropicais e o saneamento no Estado do Amazonas (1890-1930). Dissertação (Mestrado) - Programa de Pós-graduação em História das Ciências e da Saúde, Casa de Oswaldo Cruz, Fiocruz, Rio de Janeiro, 2009.

5 CARDOSO, Luciene Pereira Carris. Notas sobre as origens do Escritório Central da Comissão Rondon. Histórica - Revista Eletrônica do Arquivo Público do Estado de São Paulo, n. 43, ago. 2010.

6 A missão à bacia amazônica era composta por representantes dos governos brasileiro e norte-americano.

7 DAOU, Ana Maria. A belle époque amazônica. Rio de Janeiro: Jorge Zahar Editor, 2000.

8 MORAES, Rinaldo Ribeiro de. A navegação regional como mecanismo de transformação da economia da borracha. Tese (Doutorado) - Programa de PósGraduação em Desenvolvimento Sustentável do Trópico Úmido, Núcleo de Altos Estudos Amazônicos, Universidade Federal do Pará, Belém, 2007. p. 124.

9 A economia amazonense é, tradicionalmente, dividida em três partes. A primeira vai da colonização até meados do século XVIII, quando o interesse econômico 
se voltava para o extrativismo, a coleta das chamadas "drogas do sertão". 0 segundo momento contempla o período entre a metade do século XVIII a meados do século XIX, caracterizado pela política de incentivo à agricultura pelo Marquês de Pombal. 0 último momento inicia-se a partir de meados do século XIX, em especial a partir de 1880-1890, estendendo-se até o início do século XX. É nesse período que a borracha se torna matéria-prima indispensável à indústria para a confecção de vários produtos de uso diário, bélico, e para a construção naval. A economia brasileira volta-se para a exploração da borracha na região amazônica destinada a suprir o mercado internacional (cf. PRADO, Maria Lígia Coelho; CAPELATO, Maria Helena Rolim. A borracha na economia brasileira da Primeira República. In: FAUSTO, Boris (Dir.). O Brasil republicano - estrutura de poder e economia (1889-1930). v. 8. Rio de Janeiro: Bertrand Brasil, 2006. p. 316).

10 Considerado um caso de biopirataria por autores como FREYRE, Gilberto. Ordem e progresso. Rio de Janeiro: José Olympio, 1974.

11 FREYRE, op. cit., p. 426.

12 TOCANTINS, Leandro. Amazônia, natureza, homem e tempo: uma planificação ecológica. Rio de Janeiro: Civilização Brasileira, 1982. p. $136-137$.

13 PRADO; CAPELATO, op. cit., p. 330.

140 botânico Jacques Huber revelou a complexidade da indústria da borracha no Oriente, a qual envolvia aspectos de natureza ecológica, científica, geográfica, social, econômica, política, administrativa, então conduzidos habilmente pelo governo britânico. Sobre este assunto, ver CASTRO, Anna Raquel de Matos; SANJAD, Nelson; ROMEIRO, Doralice dos Santos. Da pátria da seringueira à borracha de plantação: Jacques Huber e seus estudos sobre a cultura das heveas no Oriente (1911-1912). Boletim do Museu Paraense Emílio Goeldi Ciências Humanas, v. 4, n. 3, p. 503-545, 2009. Disponível em: <http://dx.doi. org/10.1590/S1981-81222009000300011 >. Acesso em: 15 ago. 2011. p. 511.

15 MORAES, op. cit., p. 43.

$16 \quad$ Idem, p. 54.

17 SCHWEICKARDT, op. cit., p. 243.

18 WEINSTEIN, Bárbara. A borracha na Amazônia: expansão e decadência, 1850-1920. São Paulo: Hucitec, 1993. p. 257. (Coleção Estudos Históricos)

19 PRADO; CAPELATO, op. cit., p. 332-333.

$20 \quad$ Idem, p. 334-335.

21 OLIVEIRA, Avelino Ignácio de. Relatório da Comissão Brasileira junto à missão oficial norte-americana de estudos do Vale do Amazonas. Rio de Janeiro: Ministério da Agricultura, 1924. p. 24.

22 WEINSTEIN, op. cit., p. 298-299.

23 Hannibal Porto foi presidente da Associação Comercial do Amazonas, criada em 1902; representou o país como comissário geral nas Exposições da Borracha e outros produtos tropicais em Londres (1921), Bruxelas e Amsterdã (1924) e Paris (1927). Durante o primeiro governo de Getúlio Vargas, participou do Conselho Federal de Comércio Exterior como delegado especial da interventoria do Amazonas, e das associações comerciais do Amazonas e Tarauacá, no Alto Acre. Publicou diversos artigos em periódicos, bem como algumas obras - 0 problema da borracha brasileira e Pela produção nacional.

24 PORTO, Hannibal. 0 problema da borracha. Jornal do Commercio, $1^{\circ}$ mar. 1923. p. 3.

25 CERVO, Amado Luiz; BUENO, Clodoaldo (Org.) História da política exterior do Brasil. Brasília: Editora Universidade de Brasília, 2002. p. 202-203.

26 OLIVEIRA, op. cit., p. 25.

27 Avelino Ignácio de Oliveira formou-se em engenharia de minas e civil pela Escola de Minas de Ouro Preto, em 1916. Foi contratado pelo Serviço Geológico e Mineralógico do Brasil, no qual desenvolveu estudos de sondagens de carvão e de petróleo do Vale do Amazonas; integrou também o Conselho Nacional de Petróleo.

28 Hoje com 203 anos, o Instituto de Pesquisas Jardim Botânico do Rio de Janeiro (JBRJ) foi criado em 13 de junho de 1808 por D. João, príncipe regente à época, com o objetivo de aclimatar as especiarias vindas das Índias Orientais. 0 JBRJ, que tem como missão "promover, realizar e divulgar 0 ensino e as pesquisas técnico-científicas sobre os recursos florísticos do Brasil com vistas ao conhecimento e à conservação da biodiversidade, assim como a manutenção das coleções científicas sob sua responsabilidade", ocupa um lugar de destaque no cenário internacional no que diz respeito aos projetos relacionados à conservação da flora.

29 De tecelão de uma fábrica da Gávea, na cidade do Rio de Janeiro, jardineiro e naturalista viajante do Museu Nacional a colaborador e diretor do JBRJ, João Geraldo Kuhlmann é um cientista com uma trajetória instigante para o pesquisador que pretende analisar a participação de botânicos nas missões e expedições ao norte do Brasil no início do século XX. A relevância de suas pesquisas, bem como sua participação em missões e expedições, a interface de seus trabalhos com instituições dentro e fora do Brasil, sua parceria com cientistas de outros países, apontam para a importância de sua obra para a história das ciências. Nos primeiros anos da década de 1920 (mais precisamente em 1923), João Geraldo Kuhlmann, à época pertencendo aos quadros do JBRJ, ingressou na missão biológica belga à Amazônia, liderada por Jean Massart. A missão tinha como objetivo coletar espécies para 0 herbário de Bruxelas, na Bélgica. Em reconhecimento pelo seu trabalho, Kuhlmann foi agraciado com o título de membro da Sociedade Royale de Botanique de Belgique. BOLETIM DO MUSEU BOTÂNICO KUHLMANN, IBDF, ano 7, n. 1, jan.-fev.-mar. 1984. p. 15; HEIZER, Alda Lúcia. Notícias sobre uma expedição: Jean Massart e a missão biológica belga ao Brasil, 1922-1923. História, Ciências, Saúde - Manguinhos, Rio de Janeiro, v. 15, n. 3, p. 849-864, jul.-set. 2008; HEIZER, Alda. João Geraldo Kuhlmann e a Comissão da Borracha de 1912. In: HEIZER, A.; VIDEIRA, A. A.(Org.). Ciência, civilização e república nos trópicos. Rio de Janeiro: Mauad/Faperj, 2010.

30 CASER, Arthur Torres; SÁ, Dominichi Miranda de. 0 medo do sertão: a malária e a Comissão Rondon (1907-1915). História, Ciências, Saúde - Manguinhos, Rio de Janeiro, v. 18, n. 2, jun. 2011. Disponível em: <http://dx.doi.org/10.1590/S0104-59702011000200010 >. Acesso em: 15 ago. 2011.

31 Os membros da missão oficial chegaram ao Pará no mesmo dia do desaparecimento do presidente norte-americano Warren G. Harding (Jornal do Commercio, 3 ago. 1923).

32 COSTA, Emília Viotti da. Introdução ao estudo da emancipação política. In: MOTA, C. G. (Org.). Brasil em perspectiva. São Paulo: Difel, 1982. p. 122.

33 OLIVEIRA, op. cit., p. 29-30.

34 BOLETIM DO MUSEU BOTÂNICO KUHLMANN, IBDF, ano 6, n. 4, out.-nov.-dez. 1983. p. 21.

35 KUHLMANN, João Geraldo. Esboço de fitogeografia. In: OLIVEIRA, A. I. de. Relatório da Comissão Brasileiro junto à missão oficial norte-americana de estudos do Vale do Amazonas. Rio de Janeiro: Ministério da Agricultura, 1924. p. 421.

$36 \quad$ Idem, p. 423. 
37 O Museu Kuhlmann funcionou nas dependências do JBRJ entre 1960 e 1991, sendo substituído pelo Museu Botânico. PACHECO, Christiane de Assis. Semeando memórias no Jardim. Morpheus, Revista Eletrônica em Ciências Humanas, ano 2, n. 3, 2003. Disponível em: < http://www.unirio.br/ morpheusonline/N\%C3\%BAmero\%2003\%20\%20especial\%20mem\%C3\%B3ria/christianeassis.htm>. Acesso em: 10 fev. 2010.

38 BOLETIM DO MUSEU BOTÂNICO KUHLMANN, 1983, op. cit., p. 24.

39 OLIVEIRA, op. cit., p. 423.

40 BOLETIM DO MUSEU BOTÂNICO KUHLMANN, 1983, op. cit., p. 23.

41 SCHURTZ, William. Rubber Production in the American Valley. Washington: Department of Commerce, 1925.

$42 \mathrm{~m}$ Belém, os membros das duas missões especiais fixaram o itinerário de sua expedição. Seguiriam de Belém para Manaus, depois para Porto, navegando pelo rio Madeira. Ao chegar à Estrada de Ferro Madeira-Mamoré, velejariam pelos rios Pacanoca e Ouro Preto, no estado de Mato Grosso; os rios Beni e Madre de Dios, na Bolívia; rios Abunã e Acre, no território do Acre; rio Purus, Negro, Solimões e Javary, no estado do Amazonas; rios Amazonas, Marañon, Haullaga e Ucayali, no Peru; rios Trombetas, Tapajós, Baixo Amazonas, Tocantins, Xingu; e as ilhas do estado do Pará. Além do noroeste e norte do território nacional, os norte-americanos decidiram visitar também o estado da Bahia (OLIVEIRA, op. cit.).

43 OLIVEIRA, op. cit., p. 42

44 A redação do relatório norte-americano Rubber Production in the American Valley, publicado em 1925, coube a William Schurz. Uma cópia do mesmo se encontra atualmente na Biblioteca do Horto Florestal do Museu Nacional do Rio de Janeiro.

45 No final do século XIX, o geógrafo francês Paul Le Cointe transferiu-se para Belém, onde desenvolveu diversos estudos sobre a flora da região amazônica, publicou algumas obras sobre aquela, como Amazônia brasileira (1922) e A cultura de cacau na Amazônia (1919). Sobre a trajetória de Paul Le Cointe, ver ROMANI, Carlos. Algumas geografias sobre as fronteiras franco-brasileiras. Ateliê Geográfico, Goiânia, v. 2, n. 3, p. 43-64, mai. 2008. Disponível em: $<$ http://www.revistas.ufg.br/index.php/atelie>. Acesso em: 15 ago. 2011.

46 OLIVEIRA, op. cit., p. 47.

47 Idem, p. 102

48 Vale a pena recordar que o Acre foi elevado à categoria de estado em 1962 sob o governo de João Goulart.

49 OLIVEIRA, op. cit., p. 118

50 A balata ou maparajuba é uma árvore que produz uma goma semelhante ao látex e era utilizada no fabrico de isolantes, na goma do chiclete e em correias de transmissão, por exemplo.

$51 \quad$ Idem, p. 166

52 Idem, p. 177.

$53 \quad$ Idem, p. 222

$54 \quad$ Idem, p. 282.

55 Idem, p. 314.

56 Nascido na Rússia em 1881, Gregório Bondar graduou-se em Engenharia Agronômica pelo Instituto Agrícola da Universidade de Nancy, na França. Chegou ao Brasil em 1910, quando passou a trabalhar no Instituto Agronômico de Campinas, na Escola Superior de Agricultura Luiz de Queiroz e na Secretaria de Agricultura da Bahia. Integrou a Sociedade Entomológica de Petrogrado e a Sociedade Brasileira de Entomologia. Além disso, foi um dos criadores do Instituto de Cacau da Bahia. Desenvolveu diversos estudos direcionados para a lavoura cacaueira, bem como nas áreas da entomologia, da botânica, da fitopatologia e da geologia. GARCEZ, Angelina Nobre Rolim. Centenário de Gregório Bondar. Salvador: Instituto de Cacau da Bahia, 1981.

57 OLIVEIRA, op. cit., p. 320.

58 SCHURTZ, op. cit., p. VII.

59 Idem, p. 88

60 "(...) Como regra , o trabalhador da Amazônia tem bom tipo físico, sob exposição e com incentivo é capaz de esforço longo e contínuo. Entre os homens é possível classificá-lo como superior ao trabalhador indiano e ao javanês utilizados nas plantações de borracha do Oriente e no mínimo igual em eficiência ao trabalhador chinês".

610 documento recebeu o título de Relatório da Comissão Brasileira junto à missão oficial norte-americana de estudos do Vale do Amazonas. Uma cópia encontra-se na Biblioteca do Horto Florestal do Museu Nacional.

62 LIMA, Nísia Trindade. Missões civilizatórias da República e interpretação do Brasil. História, Ciências, Saúde - Manguinhos, v. V (suplemento), p. 163-193, jul. 1998.

63 OLIVEIRA, op. cit., p. 15.

64 Atualmente, a Fordlândia encontra-se abandonada, mas é um destino cada vez mais procurado por turistas. Sobre este assunto, ver GRANDIN, Greg. Fordlândia: ascensão e queda da cidade esquecida de Henry Ford na selva. Rio de Janeiro: Rocco, 2010.

65 No século XXI, os jardins botânicos têm, necessariamente, assumido um papel importante com projetos de conservação de seu patrimônio, ampliando a função social dessas instituições. Atualmente, no Brasil, o Centro Nacional de Conservação da Flora (CNCFlora), sediado no JBRJ, tem empreendido esforços para garantir que a conservação de plantas seja discutida sob as mais diversas perspectivas de análise, integrando a visão biológica a outros pontos de vista. Durante o Congresso Internacional de Botânica, realizado em Melbourne, Austrália, em 2011, o ecólogo do CNCFlora Miguel d'Avila de Moraes, em sua apresentação intitulada "Strengthening the foundations of plant conservation in Brazil", relacionou a história da biologia da conservação no Brasil a políticas públicas de conservação da biodiversidade, trazendo importantes contribuições sobre o papel da comunidade científica na conservação de plantas.

66 SENA, Cristovam. Fordlândia: breve relato da presença americana na Amazônia. Cadernos de História e Ciências, São Paulo, v. 4, n. 2, p. 89-108, 2008. Disponível em: <http://periodicos.ses.sp.bvs.br/scielo.php?script=sci_arttext\&pid=S1809-76342008000200005\&lng =pt\&nrm=iso\&tlng=pt $>$. Acesso em: 9 set. 2011.

67 PRADO; CAPELATO, op. cit., p. 334-335

[Recebido em outubro de 2011, aprovado para publicação em março de 2012] 